\title{
Constraints in Production and Marketing of Arecanut in Salem District of Tamil Nadu, India
}

\author{
V. Mohanraj ${ }^{1}$ and R. Velusamy ${ }^{2}$
}

\begin{abstract}
Arecanut is an important cash crop in our country. The study was carried out to ascertain the constraints faced by arecanut farmers in Salem district of Tamil Nadu with a sample size of 120, by employing proportionate random sampling technique. Majority of the respondents expressed lack of specific grading of nuts in marketing as a constraint. More than three-fourths of the respondents suggested that there should be a mechanism to regulate import of nuts from other countries and to create market potential for nuts in the local markets.
\end{abstract}

Keywords: Arecanut; Constraints; Price risk; Production; Marketing; Suggestions; Tamil Nadu

Arecanut (Areca catechu) is an important cash crop in our country and it is extensively used in nuptical ceremonies, religious rites, chewing and mastication purposes. Globally, India ranks first in terms of both area and production of arecanut with 54.07 per cent of world production (FAO, 2017). The major arecanut growing states in India are Karnataka, Kerala, Meghalaya, Tamil Nadu, West Bengal and Assam. About 6,884 ha is the total area under arecanut in Tamil Nadu. Salem district accounts for 35.00 per cent of total area under arecanut cultivation in Tamil Nadu. The farmers and traders in that area expressed that quantity of nuts harvested from the trees dropped by 50 per cent due to drought in that area. Badhe
\& Tambat (2009) reported that more than three-fourths of respondents faced a major constraint in cultivating intercrops causing decrease in the yield of nuts and transmission of disease from intercrop. Arecanut is grown mostly by marginal and small farmers with less than 2.0 hectares of land (Kasinath et al., 2019) and needs less maintenance. Thus, the identification of constraints in arecanut cultivation helps to address the constraints faced by farmers in both production and marketing, and to increase the area of arecanut. The main aim of the study is to assess the constraints and get suggestions in production and marketing of arecanut. The identification of constraints could help the policy makers and various stakeholders in approaching

1. Department of Agricultural Extension and Rural Sociology, TNAU, Coimbatore- 641003.

2. Department of Agricultural Extension and Rural Sociology, AC\&RI, TNAU, Madurai-625 104.

Received : 19-04-2021; Accepted : 11-06-2021 
and planning suitable remedial strategies for farmers in improving their livelihood.

\section{METHODOLOGY}

The study was conducted in Salem district of Tamil Nadu. It occupies first position in both the area $(2,421$ hectares) and production (3,445 tonnes) of arecanut in Tamil Nadu. Among the 20 blocks in the district, Peddanaickenpalyam, Valapady, Gengavalli and Attur blocks were selected based on the area under arecanut crop. These blocks constitute 87.28 per cent of area under arecanut in this district. 120 arecanut farmers were selected for the study by employing proportionate random sampling technique. In Peddanaickenpalayam block, 52 respondents were selected for the study due to more number of arecanut growers with more than 1,000 hectares of area. In Valapady block, 36 respondents were selected with more than 700 hectares of area under arecanut cultivation, from Gengavalli block, 21 respondents were selected and from Attur block, 11 respondents were selected for the study.

\section{FINDINGS AND DISCUSSION}

\section{Constraints faced by the Arecanut Growers in the Production and Marketing of Arecanut}

The constraints encountered by the arecanut growers in production and marketing of arecanut are presented in Table 1.

Table 1.

Constraints Encountered by Arecanut Farmers in Production and Marketing of Arecanut in Salem District

\begin{tabular}{|c|c|c|c|}
\hline SI.No. & Constraints & Number & Percentage \\
\hline \multicolumn{4}{|c|}{ I Production constraints } \\
\hline 1. & Drought & 120 & 100.00 \\
\hline 2. & Implements at high cost & 50 & 41.67 \\
\hline 3. & Lack of trainings on arecanut cultivation & 120 & 100.00 \\
\hline 4. & Premium for crop insurance is high & 19 & 15.84 \\
\hline 5. & Labour scarcity at seasonal time & 70 & 58.34 \\
\hline 6. & Organic compost rate is high & 2 & 1.67 \\
\hline 7. & High cost of drone spraying of chemicals & 2 & 1.67 \\
\hline \multicolumn{4}{|c|}{ II Marketing constraints } \\
\hline 1. & No exclusive market for arecanut & 88 & 73.34 \\
\hline 2. & Price fluctuations & 97 & 80.84 \\
\hline 3. & Middlemen involvement & 97 & 80.84 \\
\hline 4. & No specific graders in marketing & 101 & 84.17 \\
\hline 5. & Importing of nuts affects the price & 93 & 77.50 \\
\hline
\end{tabular}

(*) Multiple responses obtained 
The results show that $100 \%$ of respondents had expressed that drought and lack of trainings in arecanut cultivation as the major constraints faced by farmers in arecanut cultivation. The drought experienced during the last five years had drastically reduced the area under arecanut cultivation. About 500 hectares of area under the areca palms had withered due to the effect of drought. For this, farmers are in need of trainings on improved practices to mitigate the drought. 58.34 per cent of respondents in the study area expressed labour scarcity at peak season as one of the major constraints. Only a meagre percentage of respondents ( 1.67 per cent) expressed that high cost of organic compost and high cost of drone for spraying of chemicals as constraints.
Majority of the respondents (84.17 per cent) had expressed lack of specific grading of nuts in marketing as a constraint. The lack of specific grade of the nuts affects the price of nuts in the market, creating a negative impact on the farmers who have good quality nuts.

\section{Suggestions}

It is inferred from Table 2 that 100 $\%$ of respondents suggested that training on arecanut cultivation is needed to overcome the production and marketing problems. The training on improved technologies on arecanut cultivation is to maximize the production.

Majority of the respondents $(83.33$ per cent) suggested that timely \& locationspecific market information would help the

Table 2.

Suggestions given by the Arecanut Growers to overcome the Constraints

$(n=120)^{*}$

\begin{tabular}{|c|l|c|c|}
\hline Sl.No. & \multicolumn{1}{|c|}{ Suggestions } & Number & Percentage \\
\hline \multicolumn{3}{|c|}{ Suggested measures on production } \\
\hline 1. & Subsidy for purchase of implements & 50 & 41.67 \\
\hline 2. & Subsidy to purchase of organic composts & 21 & 17.50 \\
\hline 3. & Subsidy for Drone spray & 2 & 1.67 \\
\hline 4. & Training on arecanut cultivation & 120 & 100.00 \\
\hline 5. & Farm mechanization & 70 & 58.33 \\
\hline \multicolumn{3}{|c|}{ Suggested measures on marketing } \\
\hline 1. & Special market during season & 92 & 76.67 \\
\hline 2. & Creating export opportunities & 93 & 77.50 \\
\hline 3. & Import trade control & 93 & 77.50 \\
\hline 4. & Farmers groups as sellers & 81 & 67.50 \\
\hline 5. & Government procurement at field level & 85 & 70.83 \\
\hline 6. & Timely market information & 100 & 83.33 \\
\hline 7. & Specific grading for marketing of nuts & 98 & 81.67 \\
\hline
\end{tabular}

(*) Multiple responses obtained 
farmers to avoid risks in marketing. Timely market information helps the farmers to fetch better price for their produce, and it reduces the additional costs in marketing the produce. 'Specific grading in nuts should be followed in market' was suggested by 81.67 per cent respondents. The specific grades for arecanut help in exporting of nuts and fetch better price.

This article reveals the constraints of the farmers in production and marketing of arecanut with measures suggested by farmers in mitigating the constraints. The major constraint was drought and farmers would need trainings on improved farm management practices to mitigate the effects of drought.

\section{REFERENCES}

Badhe, M. M \& Tambat, R. G. (2009). Problems experienced by the arecanut growers in arecanut cultivation. Asian sciences, 4(1 \& 2), 45-46.

FAO. (2017). FAO Statistical Yearbook 2017. Food and Agriculture Organization of the United Nations.

Kasinath, B. L. Meena, B.L. Shailesh Kumar, Lal, S.V. Kapoor, P. \& Gangaiah, B. (2019). Cultivation and Marketing Knowledge level of Areca nut Farmers in Andaman \& Nicobar Islands, Journal of Extension Education, 31 (3). https://doi.org/10.26725/ JEE.2019.3.31.6343-6348. 